\title{
A CUBAN VERMILEO
}

\section{By WilliaM MORTON WHEELER}

In a brief note ${ }^{1} \mathrm{I}$ recently recorded the occurrence in Cuba of a very handsome species of the Rhagionid genus Vermileo. Knowing my interest in these insects, one of my students, Mr. Richard P. Dow, brought me 30 living larvæ which he had collected August 28 and 29, 1930, from their pitfalls in the sand under overhanging limestone cliffs at Mayari (2800 feet) and San José (900 feet) in the Trinidad Mountains of the southern part of that island. Three of the larvæ pupated after I had transferred them to fresh sand. Two failed to yield imagines, but in late October a somewhat crippled male fly issued from the third, and was readily identified as belonging to Pheneus tibialis, described by Walker some eighty years ago from Jamaica. ${ }^{2}$ This insect is of unusual interest, both on account of its peculiar larval habits and because it is the type of Walker's genus Pheneus, which now becomes merely one of the numerous synonyms of Vermileo. In the note above cited I also called attention to the existence of yet another species of this genus, taken by H. H. Smith at an altitude of 7000 feet in the State of Guerrero, Mexico. This form was described by Williston in $1895^{3}$ as Arthrostylum fascipennis, but was later ${ }^{4}$ regarded by him as synonymous with Walker's Pheneus tibialis. The description, however, shows that it must be a different species of Vermileo. Of this genus, therefore, we now know four widely and discontinu-

${ }^{1}$ In "Demons of the Dust," W. W. Norton, New York, 1930, p. 275.

${ }^{2}$ Insecta Saundersiana. Vol. I, Diptera. London, 1850-1856, p. 156, Pl. 4, Fig. 3.)

${ }^{3}$ Two Remarkable New Genera of Diptera, Kansas Univ. Quart. 4, 1895-1896, pp. 107-109.

${ }^{4}$ Biol. Centr. Diptera, 1, 1901, p. 264. 
ously distributed species in the New World, namely $V$. comstocki Wheeler of California, opacus Coquillet (possibly only a variety of comstocki) of California and New Mexico, tibialis Walker of Jamaica and Cuba, and fascipennis Williston of Mexico. The only other species, the genotype V. vermileo Linn., is confined to the Mediterranean region. ${ }^{5}$

On the approach of winter the larvæ collected by $\mathrm{Mr}$. Dow were placed in a cold room and not brought into the heated laboratory till April 1, 1931. They at once became active, excavated fresh pitfalls and greedily seized and sucked the juices out of the ants, termites and meal-moth caterpillars with which they were provided. Some of them pupated in late May and several perfect flies of both sexes emerged during the period from June 10 to July 5. A day or two before emergence the brown, sand-incrusted pupa wriggled up through the sand till one or two millimeters of its anterior end projected into the air, and a few hours before emergence vigorously thrust its entire body out till it lay freely exposed on the surface. Then, usually in the early morning, the exquisite imago escaped from the pupa-case and was able to fly within two or three hours. It is a very delicate, short-lived, positively heliotactic insect which, unless very carefully handled, loses its legs quite as readily as many crane-flies (Tipulidæ).

Comparison of my Cuban specimens with Walker's brief description of the Jamaican $V$. tibialis reveals certain slight differences which are scarcely more than varietal or subspecific. Walker, however, was not noted for the adequacy of his dipterological descriptions, so that the recovery of the true Jamaican tibialis must be awaited before the precise status of the form discovered by Mr. Dow can be determined.

\footnotetext{
5 The South European, Balearic and Egyptian localities in which this species is known to occur are listed in the "Demons of the Dust" (pp. 147-150). I there predicted its occurrence in Sicily, unfortunately overlooking the fact that it had already been taken at Taormina on that island by my friend Horace Donisthorpe (The Ants [Formicidæ] and some Myrmecophiles of Sicily. Ent. Rec. 38, 1926, pp. 161-165, 39, 1927, pp. 6-9; and the Guests of British Ants, London, 1927, p. 120 , fig. 21.)
} 


\title{
Vermileo tibialis (Walker)
}

\author{
var. dowi var. nov.
}

Female (living). Length 11-12; wing 9.5-10 mm.

Surface of body shining; rich fulvous yellow, with olive green eyes; face densely white pollinose; ocelli black; front and posterior surface of head dark brown, covered with grayish yellow dust. This becomes glistening white on the inferior posterior surface. Proboscis, palpi and antennæ pale yellow, the terminal antennal joint fulvous yellow, the arista white with blackish tip. Thoracic dorsum reddish, the mesonotum with a pair of narrow, ill-defined brown vittæ; scutellum, metanotum, pleuræ and coxæ and four abbreviated longitudinal lines on the anterior half of the mesonotum glistening white pollinose in most specimens. Abdomen with the posterior half of the tergites obscurely brownish, terminal segments and valves darker; venter anteriorly flesh-colored, sides whitish. Fore and middle legs yellow, paler than the hind legs, which are fulvous; the three terminal tarsal joints of all the legs, the distal three-fifths of the hind tibiæ and a long spot near the apex on the extensor surface of the hind femora, black. Wings smooth and glossy, their anterior borders broadly bright fulvous yellow shading into grayish posteriorly, their tips and a median transverse band, broadest near the costal border, blue black or blackish slate-colored; veins fulvous, blackish in the dark areas. Halteres fulvous yellow. Thorax and wings hairless; abdomen and legs, especially the hind pair, with extremely short and minute pubescence; orbital cilia white, short and inconspicuous.

Face and front narrow, linear, parallel-sided, of equal width. First antennal joint slender, at least twice as long as broad, second joint as long as broad, third joint slightly narrower than the second, oval, nearly twice as long as broad; arista distinctly segmented, somewhat longer than the remainder of the antenna. Thorax robust, very nearly as broad as the head, at least through the wing-insertions, and about one and one-half times as long as broad, very convex dorsally, rectangular anteriorly. Wings rather 
narrow; venation much as in $V$. comstocki, but the anterior branch ( $R$ 4) of the third longitudinal vein is more curved at the tip, the fourth posterior cell (M 3) is closed near the wing margin, forming a very short $\mathrm{M} 3+\mathrm{Cu}$ vein, and the apex of the first anal cell is so greatly contracted as to be almost closed. In $V$. vermileo the tips of the fourth posterior and first anal cell are contracted but not closed. Fore and hind tibiæ with a single stout spur; middle tibiæ with two spurs. Abdomen long and narrow, tapering at the tip; genital appendages small, the outer pair short and broadly excised distally, with rather acute anterior tips.

Male (living). Length 9.5-10 mm.; wing $8 \mathrm{~mm}$.

Differing from the female in its smaller size and more slender stature, the thorax being decidedly narrower than the head and less convex dorsally, and the abdomen much more slender and clavately enlarged at the tip, though the genitalia are small. Face and front not narrower than in the female, but the two basal joints of the antennæ are distinctly broader, shorter and more flattened.

Mounted specimens of this fly soon lose their rich fulvous color and become dull reddish and the eyes dark brown. The glistening white dust on the thorax and coxæ is absent or poorly developed in some recently emerged individuals.

According to Walker the male of the Jamaican tibialis measures 4 lines $(8.3 \mathrm{~mm}$.) though the wings measure 7 lines (about $12 \mathrm{~mm}$.). The former measurement may be readily explained as due to the shrinkage of the abdomen in drying, but the latter exceeds that of the females of the Cuban specimens. The Jamaican form, moreover, seems to have an entirely black antennal arista, the halteres having dark-colored knobs, the markings on the wings are brown instead of blue-black, and there is no dark spot near the apex of the hind femora. Walker's figure shows two spurs on the fore and hind, as well as on the middle tibiæ, but this may be a draughtsman's error.

Williston's description shows that the Mexican Vermileo fascipennis differs from tibialis in having the face bare, the dorsal portions of the three antennal joints as well 
as the arista, three posteriorly confluent stripes on the mesonotum, the pleuræ and the basal portion of the first (second?) abdominal segment, black. This segment has a yellow spot on each side. The hind femora, except their tips, the median portion of the hind tibiæ and the tip of the second joint of the hind tarsal are also black. The fourth posterior and anterior anal cell are closed as in tibialis, but the hind tibiæ have two spurs as in $V$. vermileo. The markings on the wings resemble those of the Jamaica tibialis in being brown, but the extreme tips seem to be pale. Williston's specimens were males measuring 10-12 mm., and were therefore as large as females of the var. dowi. 

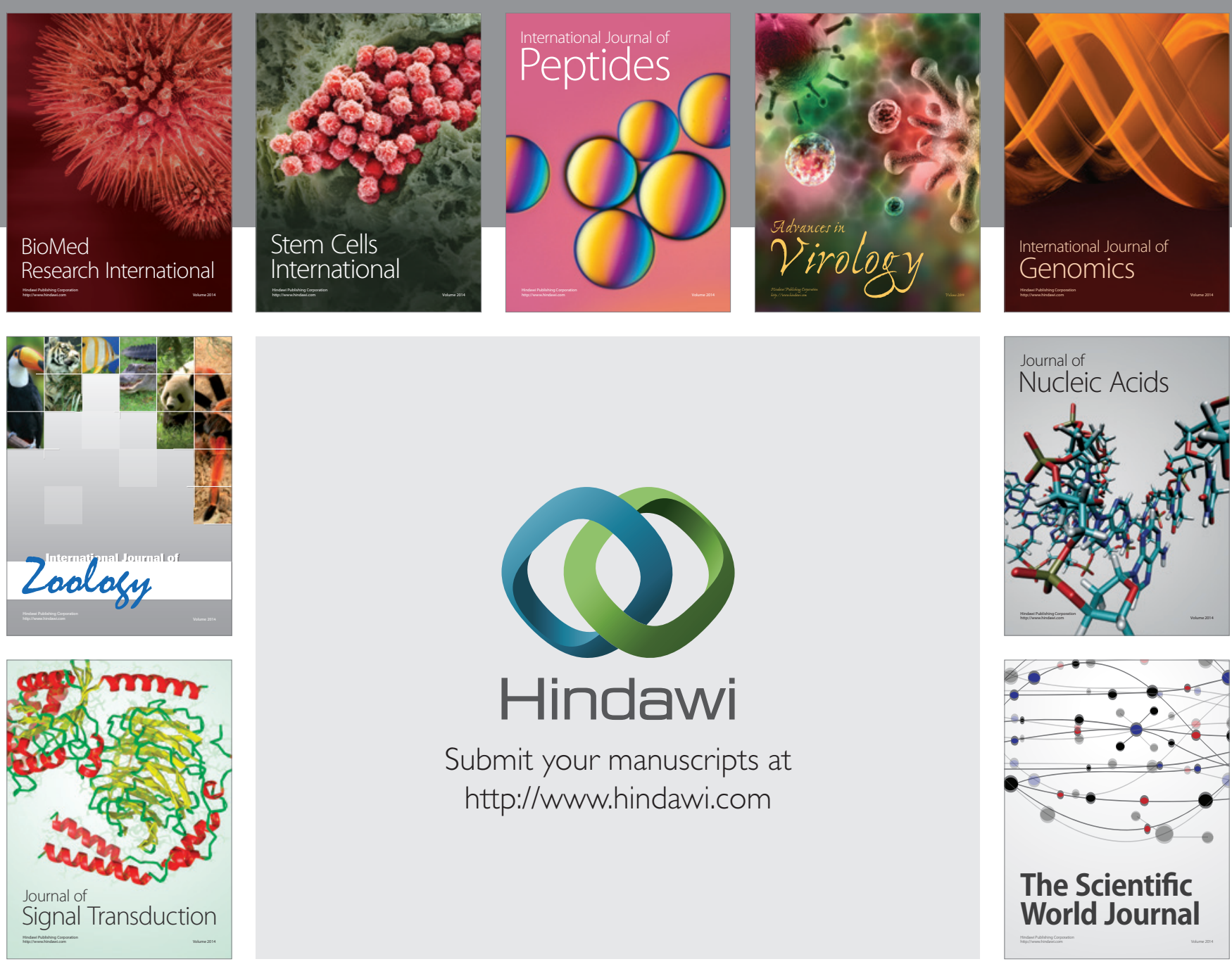

Submit your manuscripts at

http://www.hindawi.com
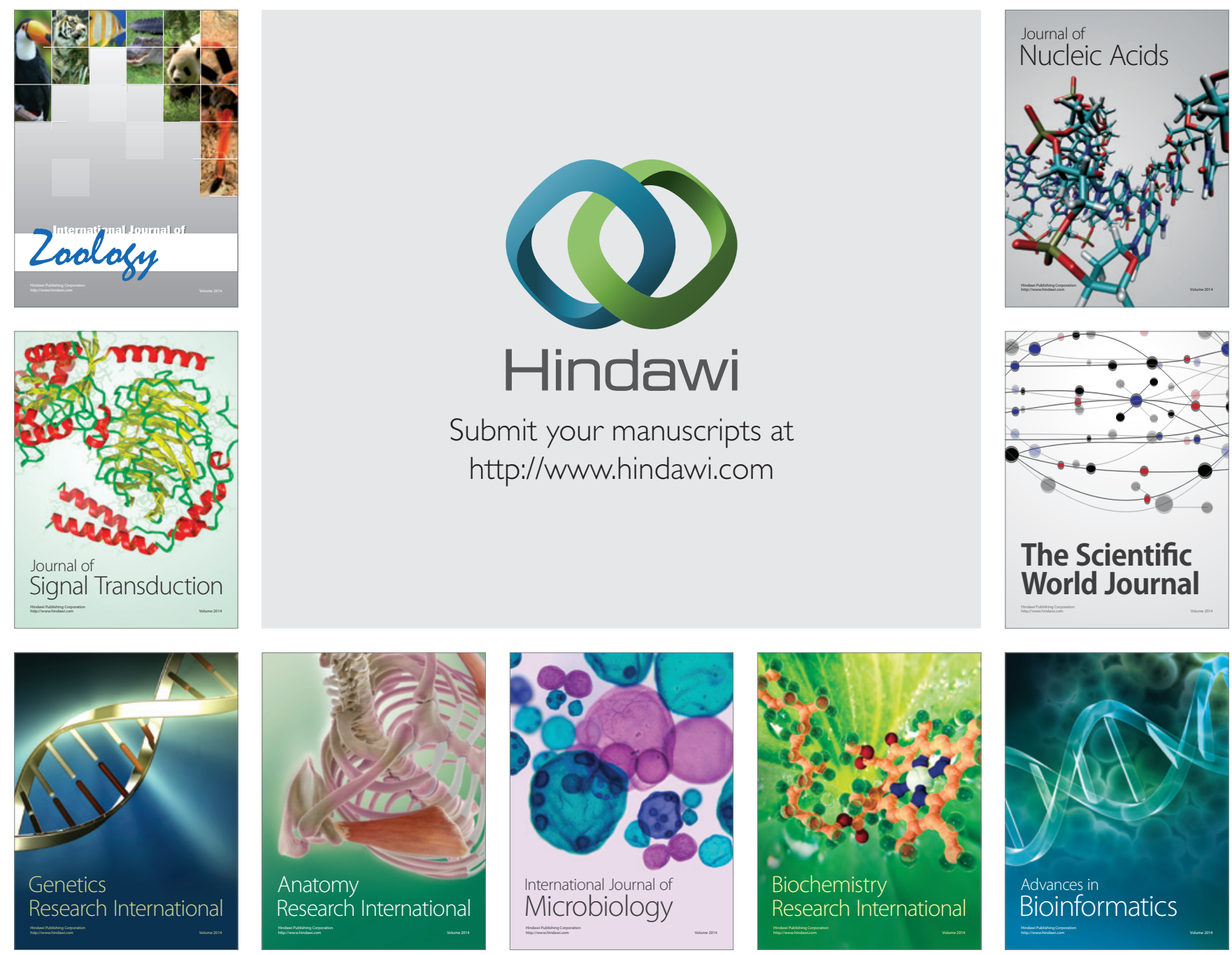

The Scientific World Journal
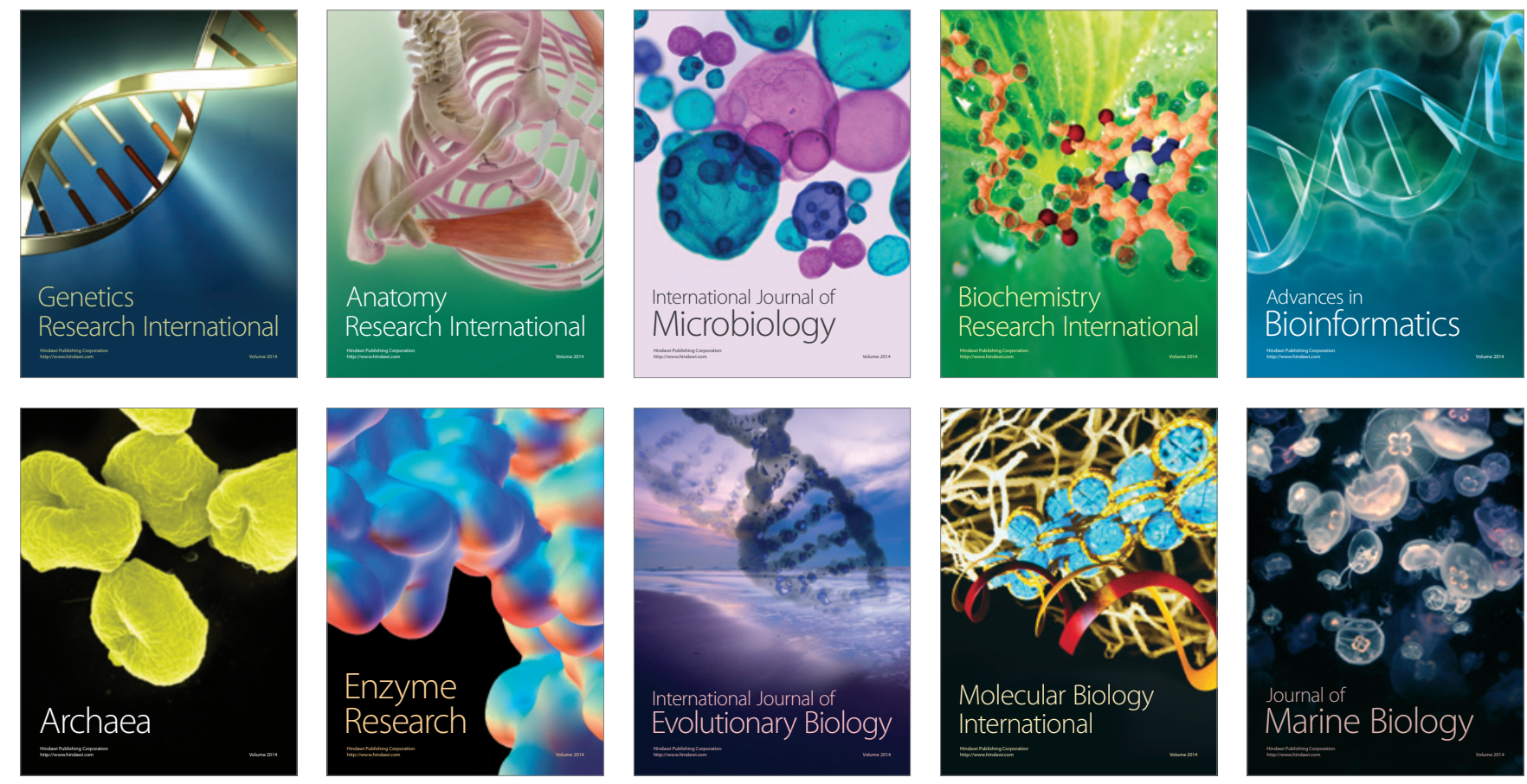